\title{
CROWNING MARSYAS: THE SYMBOLISM INVOLVED IN THE EXILE OF JULIA
}

\author{
Bianca Sanderson \& Peter Keegan
}

\begin{abstract}
In addition to the widely reported adultery committed by Julia prior to her banishment, Pliny records that Julia was seen to place a corona on the statue of Marsyas. While the accusations of adultery have been considered in regard to Augustus' so-called morality laws, or as the smokescreen for a conspiracy, the Marsyas incident has been neglected. However, the symbolism of the various traditions regarding Marsyas indicate that Julia was sending her father a powerful public message which was a factor in his decision to remove her from the city.
\end{abstract}

Julia's exile in 2 BCE has been treated as the result of a failed conspiracy disguised by accusations of debauchery or, more recently, as Augustus' response to his daughter publicly flouting his controversial 'morality' laws. ${ }^{1}$ Unhappily married to the absent Tiberius, Julia is accused by our ancient sources of 'revels' in the Forum and on the rostra. ${ }^{2}$ Upon learning of her actions, Augustus sent a letter to the Senate denouncing her actions and announcing his decision to remove her from Rome. The ancient writers are universal in condemning Julia for her profligacy, portraying her as living "so dissolute a life" 3 that she prostituted herself in the Forum. ${ }^{4}$ However, one aspect of the incident that sparked her dramatic exit from Rome is often overlooked or underrated, namely, Pliny's accusation that she placed a corona on the statue of Marsyas. ${ }^{5}$ The evidence indicates that this act was a symbolic political statement from within Augustus' own household that publicly challenged his authority, and thus must have played a part in Augustus' dramatic decision to exile Julia from Rome.

Augustus' condemnation of his daughter, it is argued, occurred after he had accepted the title of pater patriae, and immediately followed his dedication of the temple of Mars Ultor. ${ }^{6}$ Augustus sent a letter to the Senate denouncing Julia's adulteries and "nocturnal revels" in the Forum and on the rostra, and announcing her exile from Rome. ${ }^{7}$

Of all our ancient sources, Tacitus is the most lenient on Julia, and critical of Augustus. He accuses her only of adultery, and offers no further commentary on her actions or lifestyle. Considering his detailed negative treatment of Messalina and Agrippina the Younger, it is interesting that Tacitus does not deal with Julia's actions, but instead uses the opportunity to criticise Augustus $^{8}$ and his wife ${ }^{9}$ for their hypocrisy. Other sources are less specific in their allegations against Julia. Suetonius

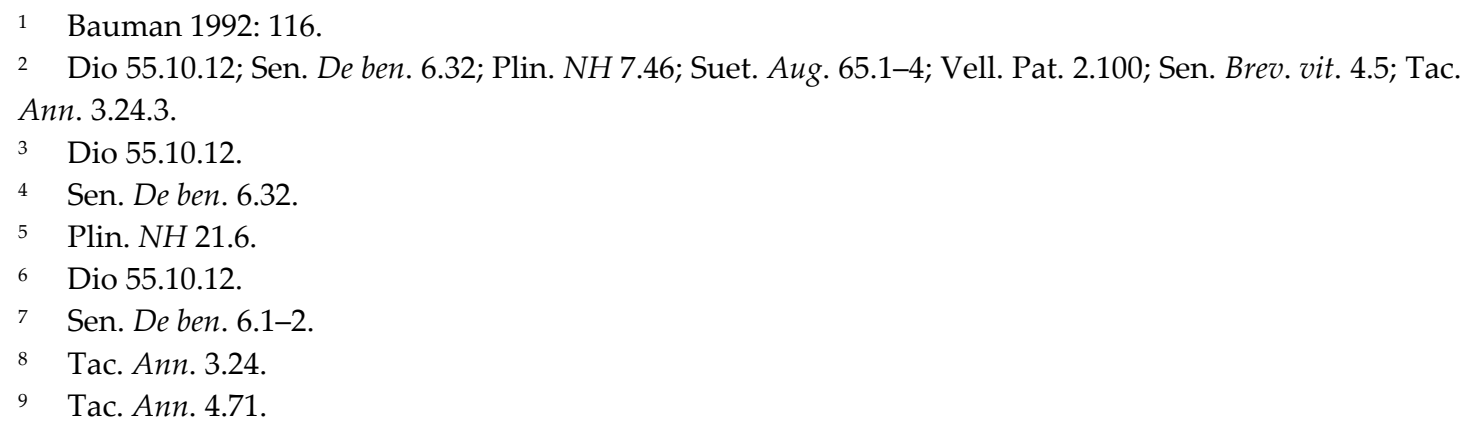


claims that she was "guilty of every form of vice"10 and Seneca that her "conduct went beyond the shame of ordinary immodesty". ${ }^{11}$ Velleius Paterculus is Julia's harshest critic - "she left untried no disgraceful deed untainted with either extravagance or lust of which a woman could be guilty as either the doer or as the object, and was in the habit of measuring the magnitude of her fortune only in the terms of license to sin, setting up her own caprice as a law unto itself". ${ }^{12}$ Dio is the only historian to give details of that night, alleging that Julia had taken part "in revels and drinking bouts at night in the Forum and on the very rostra". ${ }^{13} \mathrm{He}$ also believes that Iullus Antonius was executed for using his connection to Julia to aim for control of Rome. However, he does not claim that Julia was party to these designs. Seneca the Younger accuses her of adultery and prostitution in De beneficiis, ${ }^{14}$ but in De brevitate vitae he also appears to credit Julia with being the head of some sort of conspiracy or opposing faction - "his [Augustus'] failing years were alarmed by his daughter and the noble youths who were bound to her by adultery as if by a military oath; again he had to fear a woman in league with an Antony". ${ }^{15}$

One other action occurred that infamous night in the Forum: Pliny accuses Julia of having "in her nocturnal debaucheries, placed a chaplet on the statue of Marsyas". ${ }^{16}$ Pliny does not cite his sources for his accounts of Julia's behaviour preceding her exile from Rome, but it is believed that at least the declaration of her adultery came from Augustus' letter to the Senate. ${ }^{17}$ The significance of this act becomes more apparent as the significance of the statue is examined.

There were two traditions regarding the origins of Marsyas in the world of ancient Rome. The Greek myth of Marsyas recounts the story of a foolish satyr who finds Athena's flute and challenges Apollo to a competition. ${ }^{18}$ Naturally, he is defeated by the god; but, as punishment for his hubris, Marsyas is flayed alive. The EtruscoRoman Marsyas myth, from which the statue was based, concerned a satyr who was revered for his oratory and for imparting the knowledge of augury. ${ }^{19}$

The statue of Marsyas in the Forum Romanum is the earliest portrayal of the figure from a "specifically Roman" 20 perspective. The statue has not survived and the circumstances surrounding its erection are not recorded. Our oldest reference in the literary records is a mention in Horace's Satires, ${ }^{21}$ which unfortunately does not describe the statue but uses it as a topographical marker. The satyr statue depicted on the Anaglypha Traiana is generally accepted by modern scholarship to be a depiction of the Forum Marsyas. This figure is neither fat nor slim, and is wearing rounded shoes with

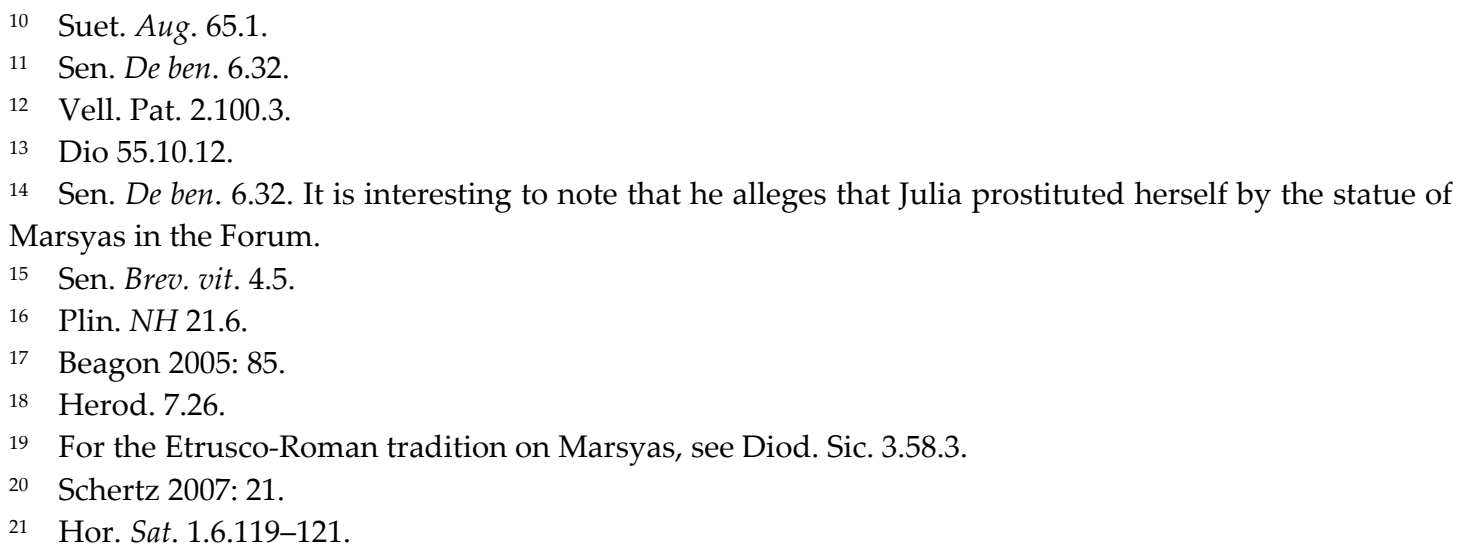


"wide, thick bands" 22 around his ankles. He has an askos slung over his left shoulder and his legs are bent. ${ }^{23}$ On both panels his head and right arm are missing detail. ${ }^{24}$ The Marsyas statues depicted in the numismatic record from the second and third centuries $\mathrm{BCE}$ corroborate the basic details about the Marsyas statue, despite minor differences. ${ }^{25}$ The bronze statue of Marsyas uncovered in Paestum in 1931 is believed to have been based upon the Forum Marsyas. He again displays the raised right arm and bended knees, as well as sharply defined ankle bands. ${ }^{26}$

Marsyas as a symbol of libertas can be tied back to his close connection to his patron god Liber. This god shared cult temple with Ceres and Libera at the foot of the Aventine, which was used as an archive for senatorial decrees. Wiseman believes that this "represented an important aspect of the libertas restored after the tyranny of the Decemvirs" ${ }^{27}$ In addition, the ludi of the Liberalia were considered by Naevius to be a medium for freedom of speech. These games were removed in the second century BCE. ${ }^{28}$ Servius also declares that the statue of Marsyas was placed in free cities as a symbol of libertas, "with his hand raised to show the city lacks nothing". ${ }^{29}$

This mythology came again to the fore during the civil wars in the first century BCE. Brutus' password at Phillipi was 'libertas', while that of the Caesarians was 'Apollo' ${ }^{30}$ Brutus is also believed to have uttered as his final words, "deadly fate and the son of Leto have killed me". ${ }^{31}$ Augustus' connection to Apollo was strengthened by the claim of his mother that he was the son of Apollo, after she was impregnated in his temple during nocturnal rituals. ${ }^{32}$ This he emphasised by placing a statue of himself with the god's attributes in his temple, and infamously attending a dinner party masquerading as Apollo during a time of famine. ${ }^{33}$

In contrast, Antony's favoured god was Dionysus, who was considered an incarnation of Liber. Antony is even recorded by Plutarch as being hailed as Dionysus upon his entry to Ephesus. ${ }^{34}$ The political symbolism of these mythical figures becomes clearer; "in each case the divine identification has to be accepted. ... Octavian is Apollo, Antony is Dionysus (i.e. Liber)" ${ }^{35}$

After the battle of Actium, Augustus transferred the power of divination to the newly built temple of Apollo, conveniently located next to his residence, and also used his powers as Pontifex Maximus to destroy all prophecies other than those contained in the Sibylline Books, and even some of those he declared to be unsound. ${ }^{36}$ This prevented potential rivals from using prophecies to legitimise their claims to

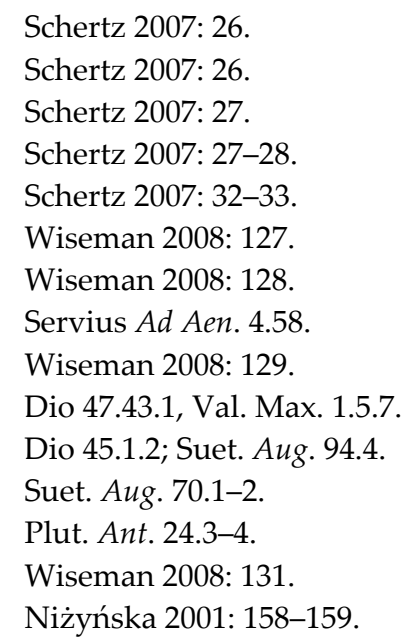


power, as well as to dispense divine approval for his own regime. ${ }^{37}$ The importance of Marsyas as an augural figure had faded with the diminishing importance of augury in the first century BCE, but Augustus also began to emphasise the Greek version of the myth, ${ }^{38}$ which did not include Marsyas' prophetic abilities, and promoted Apollo.

Joanna Niżyńska believes that by emphasising the Greek tradition, Apollo (and thus Augustus) could be presented as "a just champion over the barbaric Marsyas, who became a hubristic foil to highlight Apollo's civilized nature and demonstrate his power". ${ }^{39}$ Evidence for the propagation of the Greek tradition of the Marsyas myth contemporary to Julia can be found in Ovid's exploration of the story in both his Metamorphoses ${ }^{40}$ and his Fasti. ${ }^{41}$ Julia herself was interested in literature, and many of her companions held literary aspirations. ${ }^{42}$

Modern scholars have often claimed a political conspiracy was disguised by these accusations of adultery, but Richard Bauman finds this scenario unlikely, as Pliny ${ }^{43}$ is our only source for a conspiracy ${ }^{44}$ and, as the mother of Gaius and Lucius, Julia would soon hold a preeminent position within the state. The lenient penalties awarded to her lovers support the belief that this was not a treasonous crime. Iullus Antonius' execution was a far harsher sentence; this can be attributed to Augustus' anger at the betrayal of trust by a member of his sister's household in flouting his strict moral codes. Bauman instead believes that the rebellious spirit of Julia and her coterie of young friends intensified in $2 \mathrm{BCE}$, as did her father's reaction to the news. ${ }^{45}$ In February of that year, Augustus was awarded the title of pater patriae, which Bauman describes as "a transfer of the state into the power of Augustus, as if into the power of the head of a family", ${ }^{46}$ and with which Augustus ends his list of official achievements in the Res Gestae. ${ }^{47}$ Bauman believes that Julia and her friends demonstrated their contempt for this accomplishment by their acts in the Forum and on the rostra, and by placing a chaplet on the Marsyas statue. ${ }^{48}$ Bauman attempts to capture the importance of the statue within the episode by reference to Augustus' association with Apollo, and claiming that the chaplet crowned Marsyas as a better lawyer than Apollo. ${ }^{49}$ Although in the original Etrusco-Roman myth, Marsyas was known for his oratory, as well as for his augury, ${ }^{50}$ the ancient sources are almost silent on this aspect of Marsyas, and Bauman produces no evidence to support this hypothesis.

Elaine Fantham's recent monograph on Julia explores the possibility of these accounts of Julia's misbehaviour being the result of slander, as accusations of adultery

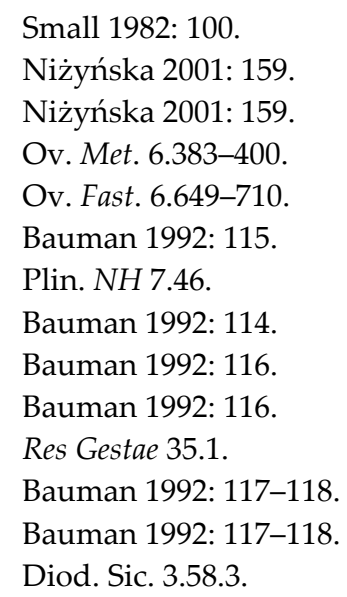


directed at high profile women could be used to discredit them. ${ }^{51}$ Julia would not have been the first popular figure to be exiled on ostensible charges of sexual debauchery, and both Julius Caesar ${ }^{52}$ and Pompey ${ }^{53}$ had divorced their wives on falsified charges of adultery when their marriages were no longer politically expedient. In addition, the accusations of debauchery during the nighttime hours in Rome meant that "no respectable citizens would have been witnesses to confirm or deny the tale". ${ }^{54}$ However, Fantham fails to supply a motive for such an action on Augustus' behalf, or to produce any further evidence for the falsity of the accusations against Julia.

She then oscillates between the idea of a political conspiracy, ${ }^{55}$ and Augustus' need to present Julia's indiscretions as a recent development after safely achieving the title of pater patriae and installing Gaius and Lucius as his legitimate heirs. ${ }^{56}$ However, a public admission of her adultery does not necessarily denote an organised exit. In fact, her hasty departure strengthens the case for Augustus' sudden anger upon discovery of her actions and, due to her high profile, some explanation for Julia's sudden disappearance would have been necessary. Seneca records that Augustus later regretted informing the world of Julia's scandalous acts. ${ }^{57}$ It was in fact Julia, by holding her revels in the public space of the Forum, who attracted public attention to her clandestine behaviour. By making her message public, Augustus could no longer ignore or conceal her scandalous conduct.

Wiseman understands the importance of Marsyas as a representation of libertas, and that Julia's decision to crown the statue was a highly symbolic gesture. However, he misinterprets her action as "a statement of libertas, which he [Augustus] interpreted as licentia and luxuria". ${ }^{58}$ He supports this claim with Seneca's description of Julia prostituting herself at the statue of Marsyas. ${ }^{59}$ However, apart from that rumour, there is no evidence to suggest that Julia equated libertas with licentia, nor was there any previous association of Marsyas with such an interpretation of libertas. Wiseman also implies that Julia may have been plotting to overthrow her father and install her teenage sons on the throne. ${ }^{60}$

So what was the significance of the chaplet? An examination of Pliny's use of the term corona reveals that, apart from discussion on which plants to include in a chaplet, it is generally used in stories as a reward for military prowess ${ }^{61}$ and victory at public games $^{62}$. Military crowns could be given for performance in battle, ${ }^{63}$ as part of a triumph, ${ }^{64}$ or even voted to an individual by the state. ${ }^{65}$ Crowns awarded at public

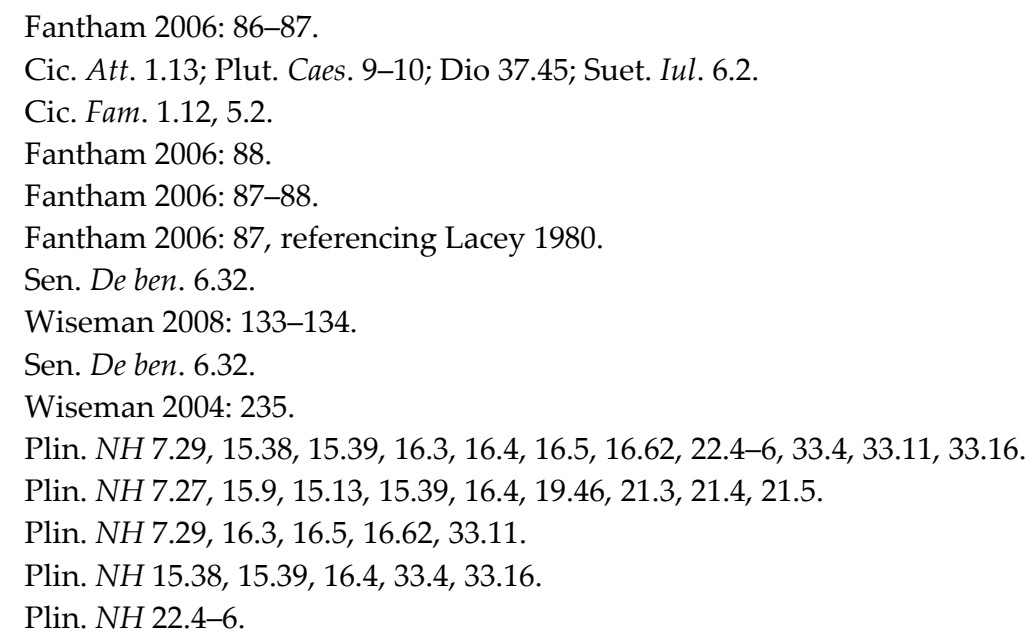


games were awarded to individuals, but Pliny notes "it is not they that are crowned, but their respective countries". ${ }^{66}$ The common theme is that they are given as a symbol of victory.

The crowning of statues could have profound political implications, such as the chaplet placed on a statue of Julius Caesar during his term as dictator. ${ }^{67}$ Although the culprit was apprehended by the tribunes L. Caesetius Flavus and C. Epidius Marcellus, Appian records that the incident, and Caesar's response, led the people to believe that he had been behind the action, and that it was part of his plan to become king. ${ }^{68}$ Pliny states that L. Fulvius was accused of "looking down from the balcony of his house upon the Forum, with a chaplet of roses upon his head" during the Second Punic War, and was imprisoned by order of the Senate until the conclusion of the war. ${ }^{69}$ P. Munatius was put in chains by the Triumviri after taking a chaplet from the statue of Marsyas and placing it upon his own head. The action was taken so seriously that the tribunes refused to intervene on his behalf. ${ }^{70}$

The full political implications of Julia's actions can now be understood. The corona was an emblem of victory. This she placed upon the statue of a figure that symbolised libertas, and that was famously known as an opponent of Apollo. This was all done in a public political space. Although we may not be able to understand Julia's intentions exactly, it is apparent that Julia was making an overt political statement opposing her father, which would have been understood by her contemporaries. It was clearly an action which Augustus could not ignore.

Her public subversion of his reforms and role within the state, both in her adultery and in the crowning of Marsyas, were no doubt the source of Augustus' anger and humiliation. Her high profile and the public context of her actions ensured that Augustus would have to deal with her challenge to his authority. Fantham makes an excellent point when she states that Julia's exile to Pandateria may have been speedily organised in order to prevent Julia from mobilising her popularity with the people of Rome to protest Augustus' decision, ${ }^{71}$ as they did following Nero's condemnation of Octavia two generations later. ${ }^{72}$

Julia's exact role within these events, therefore, may never be established with certainty. It was no doubt an episode that Augustus did not wish to be widely known, ${ }^{73}$ and consequently the surviving accounts of the event are frustratingly vague. Nonetheless, what sources remain to us reveal a tantalizing correspondence between Julia's exsilium and her decision, in Rome's premier political space, to crown Marsyas.

Bianca Sanderson

Macquarie University, Sydney

Department of Ancient History

E-mail: bianca.sanderson@students.mq.edu.au

\author{
Dr. Peter Keegan \\ Macquarie University, Sydney \\ Department of Ancient History \\ E-mail:peter.keegan@mq.edu.au
}

\footnotetext{
6 Plin. NH 7.27, also see similar sentiments expressed in 16.4.

6 Suet. Iul. 79; Plut. Caes. 61; App. BCiv. 2.108.

App. BCiv. 2.108.

9 Plin. NH 21.6.

0 Plin. NH 21.6.

1 Fantham 2006: 89.

72 Tac. Ann. 14.59-61.

3 Sen. De ben. 6.2.
} 


\section{BIBLIOGRAPHY}

Bauman, Richard A. (1992) Women and politics in Ancient Rome. London; New York: Routledge.

Beagon, Mary (2005) The Elder Pliny on the human animal: Natural History, Book 7. Oxford; New York: Oxford University Press.

Fantham, Elaine (2006) Julia Augusti: the Emperor's daughter. New York: Routledge.

Lacey, Walter Kirkpatrick (1980) '2 B.C. and Julia's adultery.' - Antichthon 14, 127-142.

Niżyńska, Joanna (2001) 'Marsyas's howl: the myth of Marsyas in Ovid's Metamorphoses and Zbigniew Herbert's "Apollo and Marsyas".' - Comparative Literature 53.2, 151169.

Schertz, Peter J. M. (2007) Seer or victim? The figure of Marsyas in Roman art, religion, and politics. Ann Arbor, Mi: UMI Dissertation Services.

Small, Jocelyn Penny (1982) Cacus and Marsyas in Etrusco-Roman legend. (Princeton monographs in art and archaeology; 44.) Princeton, N.J.: Princeton University Press.

Wiseman, Timothy P. (2004) The myths of Rome. Exeter: University of Exeter Press.

Wiseman, Timothy P. (2008) Unwritten Rome. Exeter: University of Exeter Press. 